\title{
New distribution record of Epipompilus aztecus (Cresson, 1869) (Hymenoptera: Pompilidae) in the Brazilian Pantanal
}

\author{
R Aranda ${ }^{a *}$ \\ ${ }^{a}$ Universidade Federal de Mato Grosso do Sul, Rua Oscar Trindade de Barros, 740, Unidade II, CEP 79200-000, \\ Aquidauana, MS, Brasil \\ *e-mail: rodrigoaranda.biologo@gmail.com
}

Received: July 31, 2017 - Accepted: December 4, 2017 - Distributed: August 31, 2019

(With 2 figures)

\begin{abstract}
Epipompilus aztecus (Cresson, 1869) was registered in South America in 2010. The aim of this paper is to report the first record of E. aztecus in the Brazilian Pantanal. Two female individuals of E. aztecus were collected in the northern portion of the Brazilian Pantanal in Mato Grosso State during November 2015. This new record of E. aztecus represents a range extension for the species.
\end{abstract}

Keywords: Mato Grosso, range extension, wasp, wetland.

\section{Expansão da distribuição de registros de Epipompilus aztecus (Cresson, 1869) (Pompilidae) para o Pantanal brasileiro}

\begin{abstract}
Resumo
Epipompilus aztecus (Cresson, 1869) foi registrado para a América do Sul em 2010. O objetivo deste estudo é relatar o primeiro registro de E. aztecus para o Pantanal brasileiro. Duas fêmeas de E. aztecus foram coletadas na parte norte do Pantanal brasileiro no estado de Mato Grosso, em novembro de 2015. O novo registro de E. aztecus representa uma extensão da distribuição de ocorrência para esta espécie.
\end{abstract}

Palavras-chave: Mato Grosso, extensão do intervalo, planície alagável, vespa.

\section{Introduction}

Pompilidae is a family of wasps that hunt spiders, which they feed to their larvae (Fernandez and Sharkey, 2006). The family contains about 5,000 species worldwide and in the Neotropical region 5 subfamilies are accepted (Ctenocerinae, Notocyphinae, Ceropalinae, Pompilinae and Pepsinae), with approximately 60 genera and 1000 known species (Fernandez, 2000; Pitts et al., 2005, Waichert et al., 2015). Epipompilus now is included in Pepsinae (Waichert et al., 2015). Within Epipompilus Kohl (1884), 52 species are known: 36 in Australia and 16 in America, with 15 described in the Neotropical region (Evans, 1972; Fernandez, 2000; Santos and Noll, 2010). Epipompilus aztecus (Cresson, 1869) (Hymenoptera: Pompilidae) was first described in Central America (Evans, 1966; Fernandez, 2000). The first record in South America was collected in the Serra da Bodoquena National Park (PNSB), Mato Grosso do Sul, Midwestern Brazil (Silvestre et al., 2010). The typical forest formation of the PNSB region is the semidecidual submontane seasonal forest, a remnant of Atlantic forest within the Cerrado biome. Posteriorly, Santos and Noll (2010) recorded the species in São Paulo (Cerrado biome) and Para (Amazon biome) States. This paper presents a new record of E. aztecus from the Pantanal biome in South America.

\section{Materials and Methods}

The Pantanal is one of the largest floodplains on the planet, with approximately $150,000 \mathrm{Km}^{2}$, and is influenced by biological elements of the Cerrado (Brazilian Savanna), Amazon, Atlantic forest, and Chaco (Swarts, 2000). Flood plains are known as strategic ecosystems for biodiversity conservation (Harris et al., 2005; Zedler and Kercher, 2005; Brendonck and Williams, 2000; Keddy, 2010; Alho and Sabino, 2011). The climate of the region is Aw - tropical sub humid, with dry winter and rainy summer, the average annual precipitation is between 1,000 and 1,500 mm in the northern portion (Koeppen, 1948). The flood is influenced by local rains, which occur from January to April. In the northern region Cerrado is the dominant phytophysiognomy, followed by semi-evergreen forests, semi deciduous, and deciduous seasonal forests (Nunes da Cunha et al., 2006). Field work was carried out along the entire length of the Brazilian Pantanal in 19 areas, being distributed in the Pantanal northern portion in the state 
of Mato Grosso and in the Pantanal southern portion in the state of Mato Grosso do Sul, according to the project financed by FUNDECT/CNPq N ${ }^{\circ}$ 09/2014-DCR (project $\left.N^{0} 59 / 300.188 / 2015\right)$. The report was taken at the Sesc Baía das Pedras Park ( 4, 200 hectares that belongs to Sesc Pantanal), located in the municipality of Poconé, State of Mato Grosso (16 30'20"S, 56 24'25"' W, 125 meters (a.s.1.)). Samples were taken between 08/11/2015 and 11/11/2015. The typical vegetation of the area is Cerradão (Brazilian savanna forest type) with flooded field areas. Ten sets of eight yellow and red Möerick traps (approximately 10x8x4cm length/width/depth) were installed in the field for approximately 50 hours each. One voucher specimen was deposited in the Coleção Zoológica of the Universidade Federal de Mato Grosso do Sul (ZUFMS), Campo Grande, Brazil (voucher number ZUFMSHYM00332). The specimen image was taken under Leica M205C stereomicroscope with a Leica DFC420 coupled camera. The distribution map was performed with Quantum GIS 2.18. This work was carried out under collection authorization from MMA and ICMBio (n: 48939-3 issued in 11/05/2015). Only in the indicated locality was recorded the species, in the other points of collection along the Pantanal no other specimen was captured.

\section{Results}

Two specimens of Epipompilus aztecus (female) (Figure 1) were collected with a red Möerick trap. To identify the specimens we used the key provided by Evans (1966). Epipompilus is characterized by the fore wings twice black-banded, pronotum with the collar not well differentiated from the disc, pronotum short or moderately long, propodeum with the slope low and even, almost flat posteriorly, eyes sometimes wholly covered with short hairs, and labrum strongly exserted. Epipompilus. aztecus can be identified by the following combination of characters: abdomen black, metasomal tergites 2 and 5 marked with white spots; hind tibia completely lacking spines.

\section{Discussion}

The specimens collected by Silvestre et al. (2010) were captured using a Malaise trap (one specimen) and yellow Möerick traps (two specimens), and those of Santos and Noll were collected using a Malaise trap (two specimens, one in Pará State and São Paulo State) and a Möerick trap (one specimen, São Paulo State) and did not specify the color of the traps. Here, we collected specimens using a red Möerick trap, which indicates that different methods can be used to sample E. aztecus. Despite the considered sample effort, the registered frequency appears to be low, which may indicate that it is a naturally rare species. The first record in South America (Silvestre et al., 2010), from the Serra da Bodoquena National Park, is located at a transition area of the central plateau in the state of Mato Grosso do Sul in the Pantanal plain. As suggested by Santos and Noll (2010), E. aztecus has a wide distribution and sparse records represent gaps in sampling efforts. However, the areas of the previous records are characterized by a forest-type vegetation (the same observed in Pará (Amazon biome)), a transition zone (ecotone) between Cerrado and Atlantic Rainforest (Santos and Noll, 2010), and a Riparian Forest and Submontane Deciduous Forest (Silvestre et al., 2010) (Figure 2). The region of the new record is characterized as a typical area of Cerradão (savanna forest formation type) at the northern region of the Pantanal, and it is influenced by the Amazon biome. Santos and Noll (2010) suggest that E. aztecus occurs up to $1,000 \mathrm{~m}$ a.s.1.. The report in Mato Grosso do Sul at PNSB occurred approximately at 540m a.s.1., the report in São Paulo state occurred between 505-586m a.s.1. and in Pará state was at $21 \mathrm{~m}$ a.s.l. the lowest altitude due to the proximity of the coast. We recorded the species at $125 \mathrm{~m}$ a.s.l. the lowest altitude within the continent, because it is located in the Pantanal floodplain. Recently the species was registered in Texas (USA) with the collection of a specimen and the photographic records (Fensler, 2018).

In addition to expanding the occurrence of E. aztecus to another biome, this record in the Pantanal biome provides a

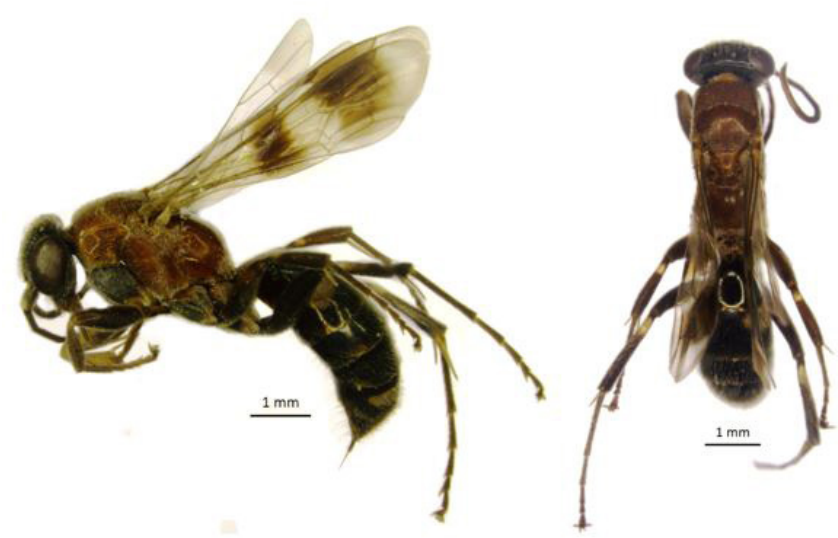

Figure 1. Female of Epipompilus aztecus (Cresson, 1869) collected in the Brazilian Pantanal. 


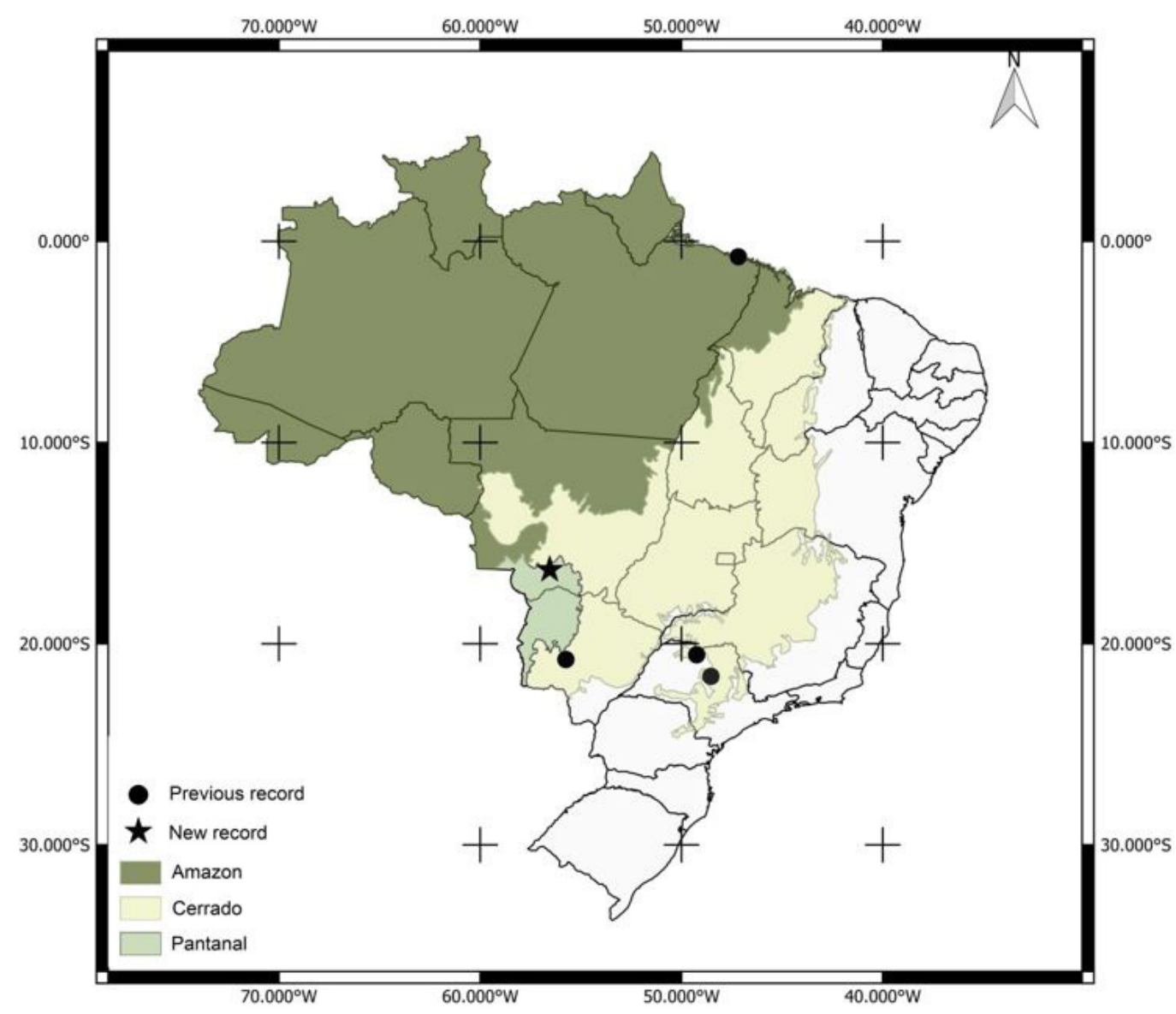

Figure 2. Geographic distribution of Epipompilus aztecus recorded in respective biomes of Brazil. $\bullet=$ previous records (Silvestre el al., 2010; Santos and Noll, 2010) and $\star=$ new record.

better understanding about the species distribution pattern. Understanding the entomofauna of the Pantanal biome helps to define important biogeographic factors that affect conservation policies of the biome.

\section{Acknowledgements}

To the Social Service of Commerce -Sesc Pantanal headquarters for authorization to use the area. To Fundação de Apoio ao Desenvolvimento do Ensino, Ciência e Tecnologia do Estado de Mato Grosso do Sul - FUNDECT for project financing $n^{\circ} 108 / 2015$, SIAFEM: 024501.

\section{References}

ALHO, C.J.R. and SABINO, J., 2011. A conservation agenda for the Pantanal's biodiversity. Brazilian Journal of Biology $=$ Revista Brasileira de Biologia, vol. 71, no. 1, suppl. 1, pp. 327-335. http:// dx.doi.org/10.1590/S1519-69842011000200012. PMid:21537606.

BRENDONCK, L. and WILLIAMS, W.D., 2000. Biodiversity in wetlands of dry regions (dry lands). In: B. GOPAL, W.J. JUNK and J.A. DAVIS, eds. Biodiversity in wetlands: assessment, function and conservation. Leiden: Backhuys Publishers. pp. 181-194.
CUNHA, C.N., RAWIEL, C.P., WANTZEN, K.M., JUNK, W.J. and PRADO, A.L., 2006. Mapping and characterization of vegetation units by means of Landsat imagery and management recommendations for the Pantanal of Mato Grosso (Brazil), north of Poconé. Amazoniana, vol. 19, pp. 1-32.

EVANS, H.E., 1966. A revision of the Mexican and Central American spider wasps of the subfamily Pompilinae (Hymenoptera: Pompilidae). Memoirs of the American Entomological Society, vol. 20, pp. 1-442.

EVANS, H.E., 1972. Revision of the Australian and New Guinean species of Epipompilus (Hymenoptera: Pompilidae). Pacific Insects, vol. 14, pp. 101-113.

FENSLER, N.A., 2018. Distribution of Epipompilus aztecus (Cresson, 1869) (Hymenoptera, Pompilidae) with a new record from Texas, United States. Check List, vol. 14, no. 1, pp. 225-229. http://dx.doi.org/10.15560/14.1.225.

FERNÁNDEZ, F. and SHARKEY, M.J., 2006. Introducción a los Hymenoptera de la Región Neotropical. Bogotá: Sociedad Colombiana de Entomología, 893 p.

FERNÁNDEZ, F., 2000. Avispas Cazadoras de Arañas (Hymenoptera: Pompilidae) de la Región Neotropical. Biota Colombiana, vol. 1, pp. 3-24. 
HARRIS, M.B., TOMAS, W., MOURAO, G., DA SILVA, C.J., GUIMARAES, E., SONODA, F. and FACHIM, E., 2005. Safeguarding the Pantanal Wetlands: Threats and conservation initiatives. Conservation Biology, vol. 19, no. 3, pp. 714-720. http://dx.doi.org/10.1111/j.1523-1739.2005.00708.x.

KEDDY, P.A., 2010. Wetland ecology: principles and conservation. Cambridge: Cambrigde University Press. 514 p. http://dx.doi. org/10.1017/CBO9780511778179.

KOEPPEN, W., 1948. Climatologia: com un estudio de los climas de la Terra. Mexico: Fondo de Cultura Econômica, 478 p.

PITTS, J.P., WASBAUER, M.S. and VON DOHLEN, C.D., 2005. Preliminary morphological analysis of relationships between the spider wasp subfamilies (Hymenoptera: Pompilidae): revisiting an old problem. Zoologica Scripta, vol. 35, no. 1, pp. 63-84. http:// dx.doi.org/10.1111/j.1463-6409.2005.00217.x.

SANTOS, E.F. and NOLL, F.B., 2010. Additions to the known distribution of Epipompilus aztecus (Cresson, 1869) and E. excelsus
(Bradley, 1944)(Hymenoptera: Pompilidae). Psyche, vol. 2010, pp. 1-3. http://dx.doi.org/10.1155/2010/562869.

SILVESTRE, R., AUKO, T.H. and CARBONARI, V., 2010. Insecta, Hymenoptera, Vespoidea, Pompilidae, Epipompilus aztecus (Cresson, 1869): First record in South America. Check List, vol. 6, no. 4, pp. 483-484. http://dx.doi.org/10.15560/6.4.483.

SWARTS, F.A., 2000. The Pantanal of Brazil, Bolivia, and Paraguay. Gouldsboro: Hudson MacArthur Publishers, 287 p.

WAICHERT, C., RODRIGUEZ, J., WASBAUER, M.S., VON DOHLEN, C.D. and PITTS, J.P., 2015. Molecular phylogeny and systematics of spider wasps (Hymenoptera: Pompilidae): redefining subfamily boundaries and the origin of the family. Zoological Journal of the Linnean Society, vol. 175, no. 2, pp. 271-287. http://dx.doi.org/10.1111/zoj.12272.

ZEDLER, J.B. and KERCHER, S., 2005. Wetland resources: status, trends, ecosystem services, and restorability. Annual Review of Environment and Resources, vol. 30, no. 1, pp. 39-74. http:// dx.doi.org/10.1146/annurev.energy.30.050504.144248. 